\title{
Integration of Economic Aspects in the Research of the Agricultural Market of Ukraine
}

\author{
By Iryna Sievidova ${ }^{1}$, Elina Pakhucha ${ }^{2}$, Olexandr Oliynyk ${ }^{3}$, \\ Tamila Oliynyk ${ }^{4}$, Serhii Plyhun $^{5}$
}

\begin{abstract}
The necessity and importance of conducting agricultural market research was substantiated. Features of the process of marketing research were identified, taking into account the specifics of agricultural production and sales according to time requirements. The basic principles on the basis of which the algorithms for conducting market research are developed and directly carried out were determined. The main requirements for conducting research on the state of the agricultural market were outlined, the most important being objectivity, impartiality and independence from personal or political interests. The factors that should be taken into account when conducting marketing research on the state of the agricultural market were determined, taking into account both controllable and uncontrollable factors of the marketing environment. The stages of marketing research that meet the requirements of the agricultural market were offered. Gross production volume of agricultural products was predicted and trends in the whole branch were discovered, a polynomial trend line was chosen because the equation of this model has the highest coefficients of correlation and determination, and so it describes the dynamics most reliably. The agricultural market was studied in terms of marketing, i.e. from the perspective of two subsystems, the first of which is represented by the supply, and the second by the demand. It was established that the supply of basic foodstuffs is realised by means of domestic production, and the demand is realised by means of internal and external buyers.

The overall price situation on the agricultural market in Ukraine was analysed and predicted. The contemporary features and problems of formation of prices for agricultural products are outlined. The research on the modern state of agricultural market gave a reason to claim about its development being rather steady, reaffirmed by the positive dynamics of gross agricultural production volume.
\end{abstract}

Key Words: agricultural marketing, marketing research, economy, development trend, agricultural market, agricultural produce.

\section{Introduction}

National food security in current socioeconomic conditions of development requires the provision of population with high-quality, ecologically safe domestic produce. Recently, the agricultural market, that had been the most perspective of all the

| ${ }^{1}$ Doctor of Economics, professor of the Department of Legal Support of Economic Activity, Kharkiv National University of Internal Affairs.

2Ph.D. of Economics, associate professor of the Department of Applied Economics and International Economic Relations, Kharkiv National Agrarian University named after V.V. Dokuchaev.

${ }^{3}$ Doctor of Economics, professor, Head of the Department of Finance, Kharkiv National Agrarian University named after V.V. Dokuchaev.

${ }^{4}$ Doctor of Economics, professor of the Department of Applied Economics and International Economic Relations, Kharkiv National Agrarian University named after V.V. Dokuchaev.

${ }_{5}^{5}$ Postgraduate of the Department of Applied Economics and International Economic Relations, Kharkiv National Agrarian University named after V.V. Dokuchaev. 
market types, does not provide the balance between supply and appropriate cost. This indicates the absence of correlation between supply and demand that has to be provided by marketing research. Besides, the effective choice of a marketing research mechanism as a marketing foundation for agribusiness development gives the possibility of growth and increase in efficiency of agricultural enterprises' activity.

Marketing research is meant to help decrease the level of uncertainty to be overcome by producers. Marketing research represents the activity that changes its form since it takes facts, numbers and other types of unprocessed data and transforms it into information that will be useful for decision-makers. The specifics of agricultural marketing are linked to the specificity of agricultural production and these differences influence the conduction of marketing research on agricultural products market. The effectiveness of marketing activity can only be estimated if the whole system of running agricultural business is considered. If at any stage the information delivery fails, it can be assumed that further estimates will be imprecise and will not yield the biggest useful economic effect that would have been possible to achieve with complex action on all stages. The algorithm for conducting research is also defined by the specificity of agricultural marketing. Despite that, there exist conventional principles that determine the algorithm for conducting research: monitoring the dynamics of consumers' demand considering development trends, using demand data during development, making and implementation of economic decisions; orientation of production to meet the requirements of the market with the goal of increasing the effectiveness of enterprise activity; the influence on the demand and its formation in the direction needed by the enterprise, using marketing tools that would provide the maximal relevant effect.

Thus, the tasks of marketing research are: acquiring more detailed understanding of consumers' needs; reducing risks of unsuccessful product launch or business organisation as a whole and predicting future trends, allowing the implementation of necessary corrections for further development. The results of marketing research provide a connection between producers and consumers, as well as obtaining competitive advantage in market conditions.

\section{The Market Research Conducting - A Literature Review}

The origin of marketing activity of agricultural enterprises is marketing research which assists in conducting the analysis of market problems and the enterprise's ability to achieve competitive advantage on the target market, and therefore, to satisfy consumers' needs in the best way, since in the conditions of increasing competitiveness, it is necessary to possess current market information about demand, supply, price level, capacity of the potential market (Rudnytska, 2007).

The main problems of conducting marketing research in the agricultural enterprises' activity were determined (Ilchenko, 2016). Amongst them of the largest importance, according to the study, are: insufficient qualification level of human resources, the problem of incomprehension of the role of marketing research by the leadership of agricultural companies, mistrust to researchers and saving money precisely on marketing, and especially on research. 
In the study (Tarasyuk, 2019) it was proven that a vital need arose for forming organisational marketing structures that provide information gathering, its analysis and the conducting of marketing research. The authors proposed basic ways of improving the management of agricultural enterprises' marketing activity by creating a full-fledged, effective marketing department, as well as development and implementation of agricultural enterprises' marketing strategy.

In the work (Subotina, 2018) it was shown that the main directions of marketing research in the AIC sector are: research on the agricultural market, its capacity, conjuncture or agricultural product sales, studying the competitors' activity practice, researching consumers' reaction to product introduction. Therefore, it is vitally important to properly organise the selection, development and implementation of marketing research projects into the AIC, since such research is an essential tool for substantiating and making timely, effective management decisions.

Research (Zuzaku, 2015) shows that marketing research includes consultation, idea generation or solving of posed problems; good research often includes all of these elements. This is also the time of changes for the branch of marketing research, hence the need to clearly define its boundaries. The author described how to invest in marketing research that will provide an increase in profitability not just for separate agricultural companies, but for agriculture as a whole and for further rural development.

In the article (Yerankin, 2015) the categorisation system was examined and propositions were made about improving the market conjuncture research process at its different stages. As a result of the research it was proven that there is a danger of uncontested implementation of marketing research results into business processes, which is explained by certain objective and subjective problems of conducting research in the AIC of Ukraine. In the work recommendations were provided about the active usage of innovative tools and methods for conducting marketing research on the basis of global experience.

As indicated in the study (Holz-Clause, 2018), market research should not be overly sophisticated, expensive or complicated; it stresses that the most important is obtaining reliable information that can be used for the development of entrepreneurial activity. As main components of the market analysis process the study includes the estimation of capacity of the market for goods or services, prediction of market share, gathering of market information and competition analysis.

In the work (Kovinko, 2017) the assessment of business activity of domestic agrarian enterprises in conditions of international diversification was conducted. The structure of production and consumption of agricultural produce in Ukraine, as well as the dynamics of export and import operations of agricultural goods in Ukraine were analysed. This development allowed to determine the economic potential of agrarian enterprises in Ukraine in conditions of international diversification of business activity.

Research (Pchelyanska, 2019) provides evidence that the modern concept of agricultural marketing must be characterised by such components as: social responsibility, "green" marketing, marketing for partner relationships, integration of marketing activity. This concept provides significant advantages for consumers, society and market subjects' partners. 
Methodological bases for marketing research in Microsoft Office Excel were developed in the applied marketing field (Alvin \& Bush, 2005), allowing for assessment of market conjuncture and for development of effective measures for increasing market demand. Methods for calculating a predicted value of supply and demand for agricultural produce were suggested (Galchynska \& Nalyvayko, 2017). They are based on building statistical models using MS Excel tools. The authors proposed to build a graphic diagram using available statistical data, to this diagram the trend line expressed by an equation is added. In the case of predicting supply and demand for a certain type of produce, the data about supply and demand for this produce during a certain period will be the basis for modelling the prediction.

It is known that production and sales activity of agricultural enterprises does depend on the influence of seasonal changes. It is necessary to take into consideration this influence in the process of demand control using methods for economic prediction. The proposed Moving Average method (Tikhonova \& Skripnik, 2017) is intended to determine trends of seasonal changes of market supply and demand and allows to estimate the demand for agricultural produce in the next periods.

Article (Tubolets, 2016) determines that the organisation of marketing research can be done in several certain ways, amongst which such were noted: one that implies the responsibility for collection and analysis of information being taken by all of the enterprises' subdivisions; one that implies the existence of a localised marketing service in the enterprise and several other ways. Authors substantiated the use of certain components of marketing research; this helps optimise the research process itself.

Research (Grundey \& Daugelaite, 2009). is built on an innovative approach related to the development of business partnership, using elements of business relationships and internal marketing. The authors proposed a hypothetical model of business partnership development using the basis of internal marketing. It implies the existence of a direct connection between internal marketing and the marketing of relationships.

An important aspect of enterprise activity in any branch of economy is the monitoring of the competitive environment. On the basis of this article (Krasil, 2015) proposes a model of marketing research on the competitive environment, allowing to facilitate the control over posed tasks and to carry out marketing control in every step of the business process during different time periods.

The authors of the work (Pakhucha, Sievidova, \& Pakhuchyi, 2018) formed basic ways of increasing competitiveness of enterprises and types of produce in the conditions of the global market and of the European vector of economic development.

It is possible for heads of agricultural enterprises that work near large settlements and other important markets to assess the usefulness of marketing research within the framework of market orientation and an active innovative position (Mirzaei, Micheels, \& Boecker, 2016). The authors insist that, according to the research results, producers must grasp that if they are working in a highly competitive environment, they need to be active in regard to the introduction of new products which meet the requirements of potential consumers. If the competitiveness is increasing in this segment, then the value of marketing research and an active approach to the improvement of own competitiveness are of high importance. 
In the work (Iryna Sievidova et al., 2019) authors suggest the behaviour of an agrarian enterprise on the market be modelled by way of reaching Nash equilibrium under different scenarios of competitors' actions and different volumes of information about market conditions. It is suggested to use the applied tools of game theory to determine the optimal action strategy for an agrarian enterprise for the tasks of integrating it into the wholesale market.

By researching the connection between supply and demand for foodstuffs, research (Monaco et al., 2017). presents a toolset for fact-finding, that is implemented and used in a comparative research on several European urban regions. Model of adequate reaction to food needs that was proposed by the authors considers the main features of regional agri-food systems, while also providing understanding of relations between localisation, global competitiveness of agricultural sectors and changes in the usage of land resources. Researchers (Lisna, Pivavar \& Ponomarenko, 2018) substantiated the choice of directions of increasing the effectiveness of using enterprise's marketing potential and developed appropriate measures for following them. This stipulates a need for a thorough marketing research on agricultural enterprise's business activity, for determining the features of market segmentation and for establishing key advantages that provide constant positions for producers on the competitive scene.

Article (Boiko V, Kwilinski, Misiuk, \& Boiko L, 2019) explains competitive advantages of wholesale markets, highlights the state's main activity directions and benefits in regard to creating a network of wholesale agricultural markets. On the basis of the acquired results authors made a conclusion about the expedience of creating a network of wholesale food markets that can ensure the economic security of producers and satisfy consumers' needs.

Considering the significant contribution into the research on this problem, it behoves to note that some aspects remain insufficiently studied. It is necessary to more thoroughly study marketing research on the state and agricultural market development trends with consideration for the specifics of this branch. The essence of the research lies in determining the optimal algorithm for conducting marketing research and in marketing assessment of the state and development of the agricultural market. Systematic market research in modern conditions is an important tool for reducing the risk of uncertainty and for survival in a competitive environment.

\section{Specifics and algorithm for conducting marketing research on the state and development trends of agricultural market}

The main task of research is to provide precise and objective information that reflects the situation. Features of marketing in the agricultural branch of the economy are related to: features of agricultural production; consumers' demand; intense competition over the similarity of produce; problems of sales; low level of purchase price due to price disparity; ignoring the demands of processing enterprises; lack of information about sales markets; absence of strategy for effective produce promotion on the market.

Considering this, the algorithm for the marketing research includes a sequence of stages, consisting of a certain sequence of steps. The most important decision that must be made by every enterprise is to determine the problem that needs to be studied and 
solved using marketing research. It is important for the researched problem to be clearly stated. An overly broad definition will lead to a large amount of unnecessary information; an overly narrow definition may mean that it will be needed to conduct further research. The goals of the research should be specific, measurable, attainable, appropriate and precise in terms of time. This will reduce the risk of confusion or misunderstanding during research, while also facilitating the evaluation of research results.

The next step is the assessment of the abilities of the marketing research (Krasovska, 2018), that is determined by the possibility of acquiring the necessary marketing information, the existence of necessary time and resources, the predicted estimate of research efficiency, the definition of the full list of alternative actions for solving the problem.

The goal of a marketing research can be such (Polova \& Tsikhanovska, 2018): timely recognition of a possible introduction of a new competitive produce type to the agricultural market; formation and development of a prestigious image of agricultural produce; creation of a flexible mechanism for adjusting the process of the transition of life cycle periods of agricultural produce, taking into account the variability of the demand for the produce on the agricultural market; timely provision of information about the advantages of a specific type of produce.

As a result of a conducted research it is necessary to confirm or refute the hypotheses that were put forward on the first stage of research. Thus, conducting this research it is necessary to remember that its goal is not to acquire information, but to describe a certain phenomenon, to evaluate its dynamics or structural changes, to explain certain regularities of its existence (Krasnorutsky \& Danko, 2009).

Information analysis includes the transformation of the array of acquired data into meaningful information, which helps with decision-making. The end products of a marketing research are conclusions and recommendations. It is necessary to clearly present any recommendations about a problem or recommendations about solving a given problem situation. The results of a marketing research are a basis for demand control, that includes not just determining the ability of the enterprise to adapt to market conditions, but also to purposefully influence customer's choice and decision-making.

\section{Application of the algorithm for marketing research for determining the state and development trends of agricultural market.}

Providing a proper level of production in accordance with the demands of the state and with the needs of social security of the population is one of the main tasks for the commodity policy of domestic producers. On the whole, the development of the agricultural market in Ukraine is sufficiently stable, as the dynamics of gross agricultural production suggests. However, it is important to note that modern agricultural production is characterised by the trends of the yearly increase in domestic production cost, which in turn leads to the increase in the share of imported produce in the food sector and to the decline of food security. In particular, Ukraine holds the 63rd place among 113 countries of the world in the general rating of food security with considering the influence of natural conditions (Pakhucha, Filimonov \& Leshchenko, 2019). 
Formation of a positive trend in agricultural produce market development in turn depends on the following factors: low elasticity of demand on the produce, which provides the stability of product sales volume; high level of standardisation for produce; the existence of pure competition on the markets of individual types of food products; the interdependence of the food market and adjacent commodity markets. Graphically the prediction of gross agricultural production for the farms of all categories in Ukraine is presented on the fig. 1 .

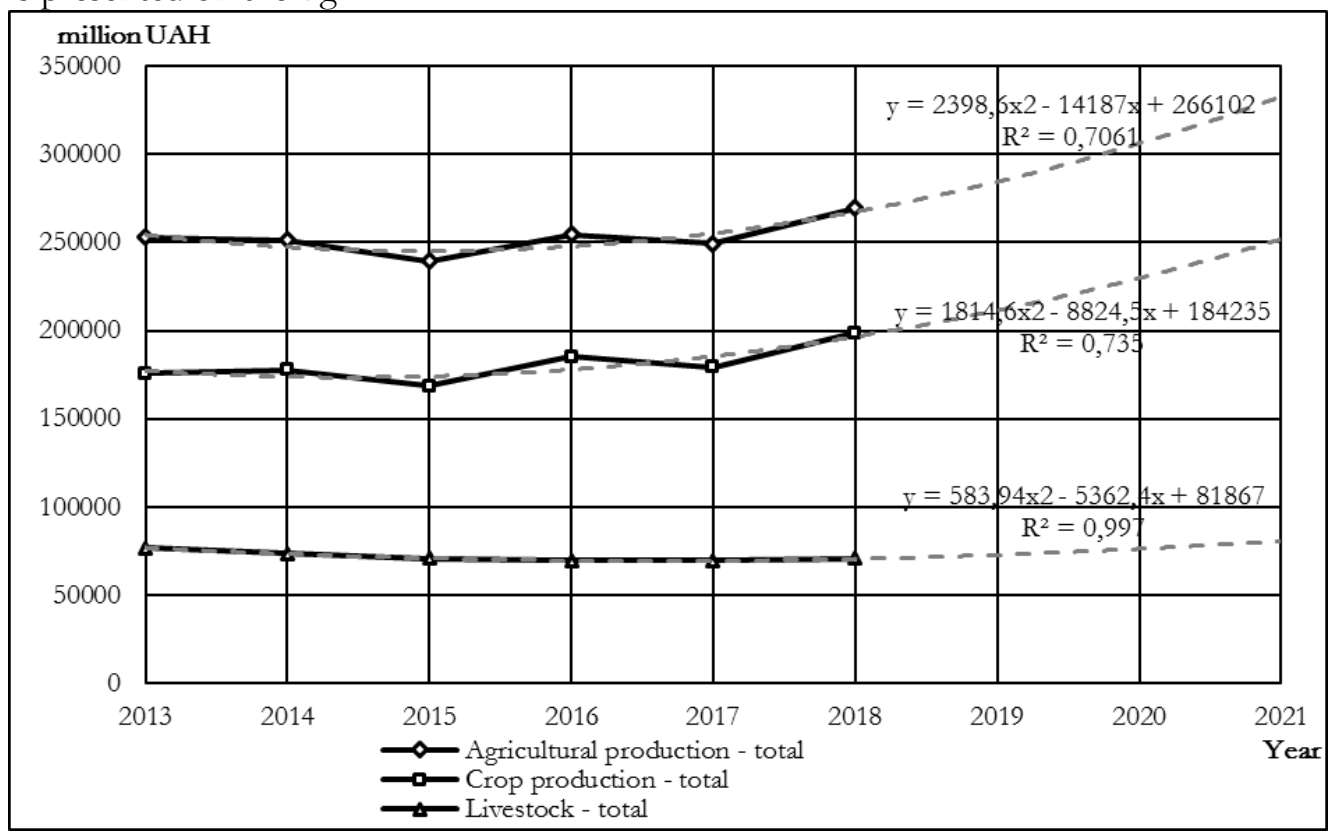

Figure 1. The dynamics of gross agricultural production for the farms of all categories in Ukraine, with polynomial trend line, 2013-2018 and predictions until 2021, million UAH.

For the analysis a polynomial trend line was chosen, because the equation of this model has the highest coefficients of determination ( $0.706,0.735$ and 0.997 respectively), i.e. it describes the dynamic series most reliably.

The model of agricultural production is expressed by the following equation. Six periods from 2013 to 2018 serve as the basis for the model, therefore for the prediction of the next period of 2021, the predicted level of the total agricultural production volume equals:

$\mathrm{Y}_{\text {prediction }}=2398.6 \times 9^{2}-14187 \times 9+266102=332705.6$ million $\mathrm{UAH}$

The predicted level of crop production volume equals:

$\mathrm{Y}_{\text {prediction }}=1814.6 \times 9^{2}-8824.5 \times 9+184235=251797.1$ million $\mathrm{UAH}$

The predicted level of livestock production volume equals:

$\mathrm{Y}_{\text {prediction }}=583.94 \times 9^{2}-5362.4 \times 9+81867=80904.6$ million $\mathrm{UAH}$ 
On the whole, the dynamics of agricultural production volume in Ukraine cannot be sufficient to give claims about the stabilisation of the economy, therefore, its further increase will depend on the ability of domestic producers to adapt to the new conditions and requirements of the market and on the governmental support directed at the stabilisation of economic and political situation. On the basis of the conducted research it is possible to conclude that in current economic conditions the development of agricultural market is largely spontaneous.

The negative influence on the formation and development of the agricultural market is exerted by crisis events of the national economic system, accompanied by a decrease in the population's income, and therefore in its purchasing power. The consequence of this is a decrease in demand for basic food products (Zveryakov, 2012). One of the directions for increasing the effectiveness of agricultural market functioning is to increase produce quality and safety, to expand its range and to provide price parity (Plyhun, 2018). This is also a factor when considering the urgent need for domestic agricultural producers to enter foreign markets (Sievidova, 2013).

Even though the balance of supply and demand for basic food products may facilitate the optimisation of the production cost, the approaches that are based on these assumptions cannot determine the connection between food sovereignty, food requirements, international trade and indirect changes in the usage of land resources. From this approach two main problems arise. Aside from the added cost, agricultural production is also characterised by its internal production cost expressed by the price of raw food products inside farms. This aspect is often disregarded during the analysis of food balance. In this case the analysis does not show the connection between local and market conditions and the chances of improvement in the primary sector. Besides, using national statistics does not allow for the fixation of local (or regional) origin of food products, and connected data does not actually present different regional contexts on the national level. However, we know that the demand appears on the regional level, where respective agricultural subjects are active, where effective policy exists and where the rules and necessary measures are set.

Therefore, arises the need for research on relations between food supply and demand that considers the strategic role agriculture may play in the extensive development of production facilities, consumption and restoration of resources (table 1).

Table 1. The balance of basic food supply and demand, ths. tons. (year 2018 and marketing year 2019)

\begin{tabular}{|l|l|l|l|l|l|l|l|l|l|l|l|l|}
\hline \multirow{2}{*}{ Indices } & 2018 & 2019 & 2018 & 2019 & 2018 & 2019 & 2018 & 2019 & 2018 & 2019 \\
\cline { 2 - 12 } & \multicolumn{2}{|l|}{ Grains - total } & $\begin{array}{l}\text { Vegetable } \\
\text { oils }\end{array}$ & \multicolumn{2}{l|}{ Sugar } & $\begin{array}{l}\text { Milk and } \\
\text { dairy } \\
\text { products }\end{array}$ & $\begin{array}{l}\text { Meat and } \\
\text { meat } \\
\text { products }\end{array}$ \\
\hline Produce supply & $\begin{array}{l}76 \\
022\end{array}$ & 78076 & 2317 & 6800 & 2090 & 2190 & $\begin{array}{l}10 \\
279\end{array}$ & $\begin{array}{l}10 \\
200\end{array}$ & 2640 & 2680 \\
\hline $\begin{array}{l}\text { Internal market - } \\
\text { total }\end{array}$ & $\begin{array}{l}75 \\
707\end{array}$ & 77762 & 2230 & 6550 & 2089 & 2189 & $\begin{array}{l}10 \\
099\end{array}$ & $\begin{array}{l}10 \\
000\end{array}$ & 2357 & 2400 \\
\hline $\begin{array}{l}\text { Including: } \\
\text { production }\end{array}$ & $\begin{array}{l}68 \\
002\end{array}$ & 70057 & 2230 & 6550 & 1650 & 1750 & $\begin{array}{l}10 \\
099\end{array}$ & $\begin{array}{l}10 \\
000\end{array}$ & 2357 & 2400 \\
\hline
\end{tabular}




\begin{tabular}{|l|l|l|l|l|l|l|l|l|l|l|}
\hline $\begin{array}{l}\text { External market } \\
\text { (import) }\end{array}$ & 315 & 314 & 87 & 250 & 1 & 1 & 180 & 200 & 283 & 280 \\
\hline Produce demand & $\begin{array}{l}76 \\
022\end{array}$ & 78076 & 2317 & 6800 & 2090 & 2190 & $\begin{array}{l}10 \\
279\end{array}$ & $\begin{array}{l}10 \\
200\end{array}$ & 2640 & 2680 \\
\hline $\begin{array}{l}\text { Internal market - } \\
\text { total }\end{array}$ & $\begin{array}{l}22 \\
450\end{array}$ & 21488 & 187 & 580 & 457 & 1370 & 9472 & 9400 & 2241 & 2250 \\
\hline $\begin{array}{l}\text { Including: } \\
\text { consumption fund }\end{array}$ & 5605 & 5551 & 180 & 550 & 423 & 1270 & 8422 & 8400 & 2232 & 2241 \\
\hline $\begin{array}{l}\text { External market } \\
\text { (export) }\end{array}$ & $\begin{array}{l}48 \\
306\end{array}$ & 49946 & 2130 & 6220 & 198 & 500 & 807 & 800 & 399 & 430 \\
\hline
\end{tabular}

Source: own study based on local bank data, available at http:/ / wnw. ukrstat.gov.ual (retrieved 20.07.2019)

According to the estimates of international organisations (FAO, IGC, USAID) for the current marketing year it is expected that the total increase in the volume of global grain production will be between $1.0 \%$ and $1.5 \%$, primarily due to the increase in gross wheat yield by $4-5 \%$ and gross barley yield by $7-9 \%$. In return, the corn production volume is expected to decrease by 3-4\% (Moskovchuk, 2019). The total volume of export of grain and grain processing products is 3.4\% larger than in 2018. Asian, African countries and the European Union countries remain the main importers of Ukrainian grains: Bangladesh, Egypt, Indonesia - of wheat; Saudi Arabia, China, Algeria - of barley; Egypt, China, the Netherlands - of corn (UGA, 2018).

Domestic enterprises produced 3 times more vegetable oil than in the same period last year. Around $96 \%$ of oil produced in Ukraine is exported. More than half of the export, in terms of value, falls on India, China, the Netherlands. At the same time the volume of oil imports this season was 2.8 times higher than the same period last year. Palm oil, that is mainly imported from Indonesia, constitutes almost $90 \%$ of the vegetable oil import volume. According to the calculations, the internal sugar consumption increased by $4.8 \%$ when compared to the last year's level. According to the data, 409 ths. tons of sugar were exported (in July the export amounted only to 7 ths. tons); this is $24 \%$ less than the same period of the last marketing year. The most active demand for Ukrainian sugar was observed to be coming from former USSR countries: Uzbekistan, Azerbaijan, Kyrgyzstan, Tajikistan. Ukrainian import of sugar was practically non-existent (State Statistics Service of Ukraine, 2019). The decreasing trend in the production of milk and milk products still remains in Ukraine, even in the summer season. According to the data, all categories of farms produced $0.77 \%$ less, than in the same period last year. By decreasing export volume and increasing import volume, the internal market was $1 \%$ more saturated with dairy products in 2019 when compared to 2018. From the beginning of 2019 an increasing trend in the total production volume of meat by all categories of domestic farms was observed. Its rate amounted to $101.8 \%$; this led to an increase in meat product export by $7.8 \%$ when compared to 2018 , and to a decrease of import by $1.06 \%$. On the whole in 2019 an overall increase in internal market saturation with meat and meat products was observed. This increase amounted to $1.8 \%$, which exceeds the value of 2018.

In the current situation on the world's food markets of major urgency is a problem of providing competitive conditions that would allow economic subjects to effectively function. Considering that specialists classify food markets as competitive, on some of 
them there is an adverse price situation. The price of agricultural produce is an important factor that characterises the level of produce competitiveness. In the conditions of price competition, the enterprises that become more competitive are those whose produce is highly competitive in terms of price (Pakhucha, 2018a).

After the analysis (fig. 2) we have concluded that the price situation on the agricultural market is negative, because an increase in price for the main agricultural produce types over the last years was minor. Therefore, a situation arose where an increase in agricultural production does not lead to expected profit.

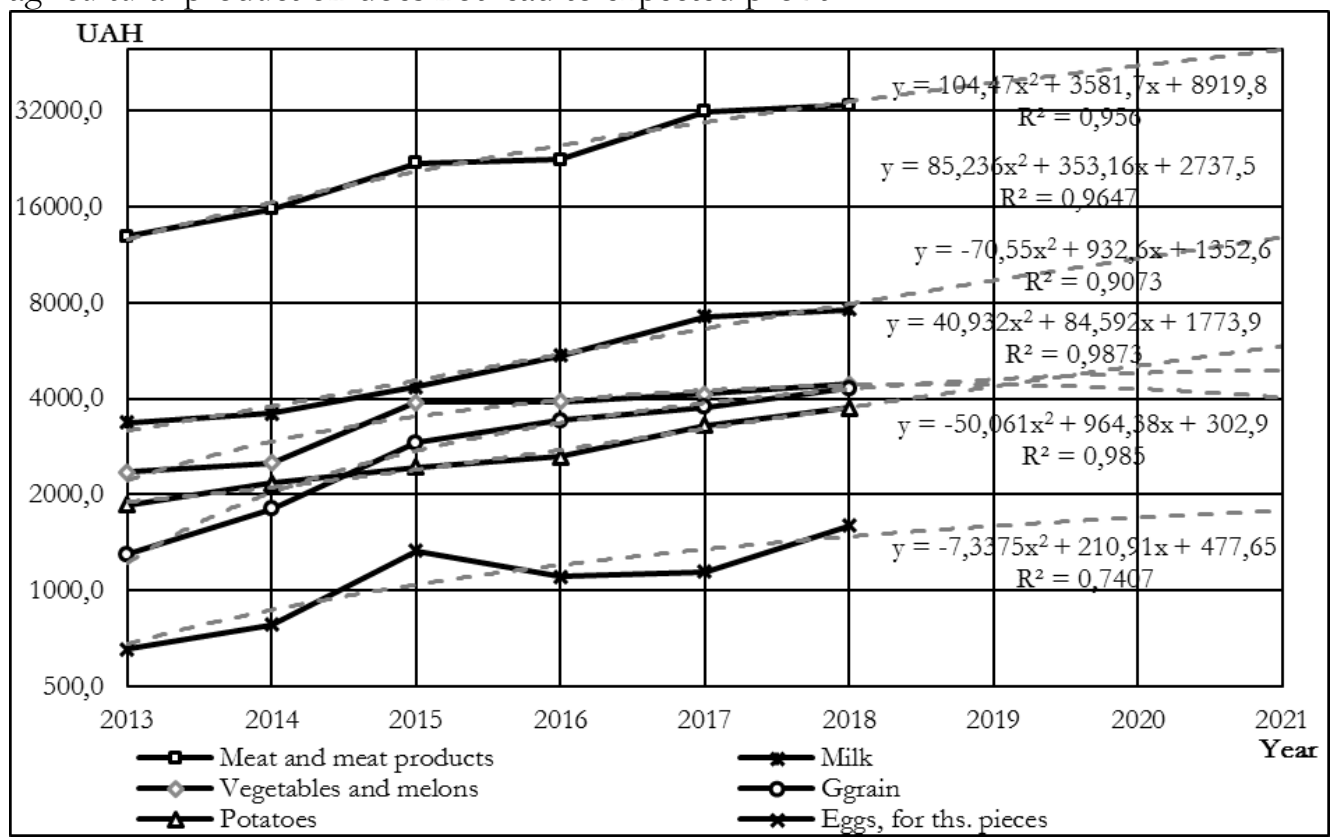

Figure 2. Average prices for agricultural produce sold by enterprises in 2013-2018 with predictions until 2021, UAH per ton.

For the analysis a polynomial trend line was chosen, because the equation of this model has the highest coefficients of determination $(0.985,0.987,0.907,0.612,0.956,0.965$, $0.741)$, i.e. it describes the dynamic series most reliably.

The predicted level of the average meat and meat products selling prices equals:

$\mathrm{Y}_{\text {prediction }}=104.47 \times 9^{2}+3581.7 \times 9+8919.8=49617.17 \mathrm{UAH} /$ ton

The predicted level of the average milk selling prices equals:

$\mathrm{Y}_{\text {prediction }}=85.236 \times 9^{2}+353.16 \times 9+2737.5=12820.06 \mathrm{UAH} /$ ton

The predicted level of the average vegetable and melon produce selling prices equals:

$\mathrm{Y}_{\text {prediction }}=-70.55 \times 9^{2}+932.6 \times 9+1352.6=4031.45 \mathrm{UAH} /$ ton

The predicted level of the average selling prices for potatoes equals:

$\mathrm{Y}_{\text {prediction }}=40.932 \times 9^{2}+84.592 \times 9+1773.9=5850.72 \mathrm{UAH} /$ ton

The predicted level of the average grain selling prices equals: 
$\mathrm{Y}_{\text {prediction }}=-50.061 \times 9^{2}+964.38 \times 9+302.9=4927.38 \mathrm{UAH} /$ ton

The predicted level of the average egg selling prices equals:

$\mathrm{Y}_{\text {prediction }}=-7.3375 \times 9^{2}+210.91 \times 9+477.65=1781.50 \mathrm{UAH} /$ ton

As the dynamics of changes in average prices of vegetable produce sales shows, the largest increase in the prices amongst products researched was noted in prices for grains (3.3 times) and meat together with meat products (2.6 times). Prediction data also bears evidence of the increase in prices for exactly these types of produce; the largest increase is expected to be in prices for potatoes $(56.2 \%)$. Regarding the prices for vegetables and fruits, the prediction states that there will be a decrease in them, especially in prices for fruits and grapes, allowing for an increase in their availability. The change in the average prices of meat and meat products points to an increase in prices during the researched period with the average increase of 2.4 times. Prediction data shows the largest increase in milk prices being almost $70 \%$ and prices of meat and meat products being almost $50 \%$. The smallest increase of only $11.3 \%$ is expected in egg prices.

The growth of prices for agricultural produce caused a significant reduction in its production, mainly in the livestock branch. This is primarily due to disadvantageous conditions for producers themselves, due to significant financial expenses and material consumption in the livestock branch.

However, it is important to note that it is the crop production whose gross production volume increased by $12.9 \%$ over the course of the researched period, while the gross production volume of livestock, with its production being more stable, decreased by $8.1 \%$. The conducted analysis gives grounds to predict that the gross volume of agricultural produce will amount to $332705.6 \mathrm{mln}$. UAH for the year of 2021 if the current trend persists. This value shows that the production volume has increased by anywhere up to $22.8 \%$. The prognosis for 2021 concludes that the gross volume of crop production will amount to $251797.1 \mathrm{mln}$. UAH showing the increase of $26.7 \%$ of production volume when compared to the level of 2018. The gross production of livestock is predicted to increase by $14.4 \%$ in 2021 and will amount to $80904.54 \mathrm{mln}$. $\mathrm{UAH}$.

The balance of production of main foods (table 1) displays the increasing trend in supply, especially for oil plants, which is explained by $90 \%$ of produced oil being exported. Sugar export is also on a sharp rise, being 2.5 times higher than last year. According to the balance calculations, the internal sugar consumption is 3 times higher in 2019 than it was in 2018. Overall, supply and demand for other produce types increases on the same percentage level (no more than $5 \%$ ) with milk and dairy products as exceptions, whose supply and demand were almost constant during the research period. In 2019 a stable decreasing trend in the total number of livestock and in the domestic dairy production volume; an increase in dairy produce imported to the domestic market was also noted.

The formation of competitive advantages in the price segment implies: firstly, a decrease in expenses on account of implementing innovative, technical, technological, organisational, commercial and administrative solutions; secondly, an increase in prices as an advantage. This advantage comes from the possibility of selling agricultural 
produce at a higher level of market infrastructure without volume fluctuations while also retaining its quality, which in turn will lead to a change in producer's position in the structure of market distribution of agricultural produce (Pakhucha, 2018b).

The conducted research illustrates that in current economic conditions the development of agricultural market is fairly stable. In this context further research may be directed at the study of competitiveness of agricultural producers on the external market and at the development of practical recommendations regarding the increase in competitiveness of domestic producers in external economic conditions.

\section{Conclusion}

The development and realisation of agricultural market research projects is an irreplaceable tool for substantiated and effective administrative decision-making. The main task of marketing research is to acquire precise and objective information because marketing information is gaining importance in the activity of any enterprise. Marketing activity is based on the monitoring of the current market situation, so the main object of marketing research is different aspects of agricultural market functioning. Main directions of agricultural market research are listed as such: evaluation of market capacity and conjuncture, research on produce sales, study of main competitors on the market, research on price situation and consumers' needs. The most important prerequisite for achieving the goals of marketing research is following the logical sequence of its stages: determining the problem; assessing the abilities of marketing research; establishing the purpose of research; developing the plan and the research project; gathering information about market state; systematisation of marketing information, analysing acquired and systematised information, preparing the report of marketing research, drawing conclusions and developing recommendations.

The research on the modern state of agricultural market gave a reason to claim about its development being rather steady, reaffirmed by the positive dynamics of gross agricultural production volume. The volume of agricultural production also shows that there is a surplus of several types of agricultural produce in the country; this allows to enter external markets. Moreover, low elasticity of demand, high level of standardisation for produce, the existence of pure competitiveness and the interdependence of agricultural market and adjacent commodity markets all determine the positive trend in agricultural market development. However, at the same time the market is functioning in conditions of the ineffective government regulatory policy, disparity of prices for agricultural produce and on material and technical resources, dependence on weather conditions, seasonal price fluctuations, low purchasing power of the population. Also, of importance becomes a problem of: lack of informational support for, and the underdeveloped system of logistics in agricultural enterprises. The existence of these and other factors calls for consideration of them in the marketing activity of enterprises, and reaffirms the importance of conducting marketing research with the purpose of the timely discovery of risk groups and appropriate administrative decision-making. 


\section{References}

Alvin, S. Burns, Bush, Ronald F. (2005). Microsoft Office Excel: Fundamentals of Marketing Research. Moscow: Williams Publishing House.

Boiko, V., Kwilinski, A., Misiuk, M., \& Boiko, L. (2019). Competitive advantages of wholesale markets of agricultural products as a type of entrepreneurial activity: the experience of Ukraine and Poland. Economic Annals-XXI, 175(1-2), 68-72. doi: https://doi.org/10.21003/ea.V175-12

Galchynska, Yu.M., Nalyvayko, I.O. (2017). Marketing research of the livestock market in Ukraine. Scientific Bulletin of the National University of Life and Environmental Sciences of Ukraine, 260, 54-64.

Grundey, D., Daugèaite, I. (2009). Developing business partnership on the basis of internal marketing. Economics \& Sociology, Vol. 2(1), 118-130. doi: 10.14254/2071-789X.2009/2-1/12

Holz-Clause, M. (2018). Conducting Market Research. Ag Marketing Resource Center. URL: https://www.agmrc.org/business-development/starting-a-business/marketbusinessassessment/articles/conducting-market-research

Ilchenko, T.V. (2016) Marketing research in the agricultural market of Ukraine: features and prospects. Scientific Bulletin of Uzhgorod National University, Vol.10. Ch.1. 125-128.

Iryna Sievidova, Tamila Oliynik, Oleksandra Mandych, Tetyana Kvyatko, Iryna Romaniuk, Larisa Leshchenko, Serhiy Vynohradenko, Serhii Plyhun (2019). Optimizing the strategy of activities using numerical methods for determining equilibrium. Eastern-European Journal of Enterprise Technologies, Vol. 6 (4), 47-56. doi: 10.15587/1729-4061.2019.187844

Kovinko, O. (2017). Marketing assessment of the state of the market of agricultural products of Ukraine: prerequisites for the intensification of international business activities of domestic agricultural enterprises. Marketing in Ukraine, 4, 32-47.

Krasil, D. (2015). Model of marketing research of the competitive environment. The Trajectory of Science, 4, 213-223.

Krasnorutsky, O.O., Danko, Y.I. (2009). Development of marketing in the market of agro-food products of Ukraine: monograph. Kharkiv: Maidan.

Krasovska, O.Yu. (2018). Algorithm of the marketing research process. Agrosvit, 21, 34-39.

Lisna, I.F., Pivavar, I.V., Ponomarenko, O.O. (2018). Marketing research and planning of marketing activities at the macro and micro levels. Business Inform, 11, 333-339.

Mirzaei, Omid \& Micheels, Eric \& Boecker, Andreas. (2016). Product and marketing innovation in farmbased businesses: The role of entrepreneurial orientation and market orientation. International Food and Agribusiness Management Review, International Food and Agribusiness Management Association, Vol. 19(2), 99-130.

Monaco, F.; Zasada, I.; Wascher, D.; Glavan, M.; Pintar, M.; Schmutz, U.; Mazzocchi, C.; Corsi, S.; Sali, G. (2017). Food Production and Consumption: City Regions between Localism, Agricultural Land Displacement, and Economic Competitiveness. Sustainability, 9, 96, 1-20. doi:10.3390/su9010096

Moskovchuk, E. (2019). Grain market forecast for the next marketing year from three leading global analytical organizations. Landlord. URL: https://landlord.ua/news/prohnoz-vrozhainist-vsikhzernovykh-u-sviti-sklade-rekordni-2156-mln-tonn

Pakhucha, E.V. (2018). Competitiveness of grain crops: regional aspect. State and Regions, 2 (101), 60-65.

Pakhucha, E.V. (2018). Price competition and its impact on the competitiveness of agricultural products. Business Inform, 9, 117-122.

Pakhucha, E.V., Filimonov, Yu.L., Leshchenko, L.O. (2019). Structural changes in Ukraine's foreign trade in agricultural products. Effective Economy, 3, URL: http://www.economy.nayka.com.ua/ index.php?op $=1 \& z=6962$

Pakhucha, E.V., Sievidova, I.O., Pakhuchyi, A.M. (2018). Economic potential of crops on the foreign market. Financial and credit activities: problems of theory and practice, Vol. 3(26), 227-235.

Pchelyanska, G.O. (2019). Marketing approaches to the formation of the agri-food market. Business Inform, 2, 202-208.

Plyhun, S.V. (2018). Efektyvnyy rozvytok ahroprodovol'choyi sfery: metodolohichnyy aspekt [Effective development of the agro-food sector: a methodological aspect]. Istoriya ekonomichnoyi dumky History of Economic Thought, p. 73-75. 
Polova, O.L., Tsikhanovska, V.M. (2018). Marketing research of the formation of a competitive environment in the food market of Ukraine. Efficient economy. URL: http://www.economy.nayka.com.ua/pdf/3_2018/8.pdf.

Rudnytska, O.V. (2007). Marketing activities of agricultural enterprises in the market of organic agri-food products. Extended abstract of PhD dissertation. National Agrarian University of the Cabinet of Ministers of Ukraine. Kyiv, Ukraine.

State Statistics Service of Ukraine (2019). URL: http: / /www.ukrstat.gov.ua

Sievidova, I.O. (2013). The impact of quality vegetables at competitive Horticulture. Bulletin of Lviv National Agrarian University. Ser: Economics of AIC, 20(1), 302-306.

Subotina, Yu.O. (2018). Features of marketing application at agro-industrial enterprises. Collection of scientific works ChDTU, Vol. 49, 68-75.

Tarasyuk, A.V. (2019). Ways to improve the management of marketing activities of agricultural enterprises. Economics of AIC, 8, 103-109.

Tikhonova, O.A., Skripnik, T.V. (2017). Synthetic moving average and a special method for determining its coefficients. Scientific works of Donetsk National Technical University. Series: Informatics, Cybernetics and Computer Engineering, 1, 108-111.

Tubolets, K.G. (2016). Marketing research as an important element of evaluation of the management system of marketing services of enterprises for production and processing of agricultural products. Agroworld, 8, 53-56.

UGA (2018). Balances of supply and demand of the main types of food resources as of 01.12.2018. URL: http://uga.ua/balances/balansi-popitu-propozitsiyi-osnovnih-vidiv-prodovolchih-resursivstanom-na-01-12-2018.

Yerankin, O.O. (2015). Modern approaches to solving problems of assessing the situation in agricultural markets in Ukraine. Bulletin of KhNAU named after VV Dokuchaev, № 4, 139-149.

Zuzaku, Agim. (2015). Market research as an important factor for the development of agriculture. Academic Journal of Business, Economics and Accountancy, 1, 77-95.

Zveryakov, M.I. (2012). Theoretical problems of the formation of the national economic system: Monograph. Odessa: Astroprint. 